\title{
ANCIENT METAMORPHIC-MIGMATITE BELTS OF THE BRAZILIAN ATLANTIC COAST: THE AFRICAN CONNECTION
}

\author{
W. S. FYFE* and O.H. LEONARDOS, Jr.**
}

\begin{abstract}
The ancient basement rocks of the African and Brazilian Atlantic margins are dominated by rocks of the granulite facies including charnockites. These rocks represent uplifted basal crust of a low P metamorphic belt. Models are presented which suggest that continental separation along such zones may not be accidental. It is proposed that separation in regions of thick granitic crust is a more difficult process. In such regions, crustal fusion turns off high level basalt injection and leads to basalt underplating. This process in turn forces mantle plumes to migrate.
\end{abstract}

RESUMO As rochas do embasamento da margem continental atlântica do Brasil e da África são constituídas predominantemente de rochas da fácies de granulito, incluindo-se charnockitos. Essas rochas representam a parte basal da crosta de um antigo cinturão metamórfico de $P$ baixa. São apresentados aqui modelos que sugerem que a separação continental ao longo de tais zonas não é acidental. Sugere-se que a separação continental em regiões de espessa crosta granítica é um processo mais dificil de ocorrer. Em tais regiões, a fusão crustal impede a injeção de basalto em níveis crustais altos, causando um underplating basáltico. Tal processo, por sua vez, força a migração das anomalias térmicas do manto (plumes).

INTRODUCTION It can no longer be doubted that about 150 m.y. ago, a successful rift formed leading to the separation of present day South America from Africa. Many types of rocks from Precambrian migmatites to Lower Cretaceous evaporites (Wardlaw and Nichols, 1972) match across the junction of rifting and one cannot help being intrigued by the problem of why continental masses rift where they do. One could consider the answer to lie in purely random phenomena but time after time ancient trends and structures appear to control later events. If events in the mantle are random, perhaps they lead to successful amplification only when they interact with certain structural situations in the continental crust. Only recently has sufficient data become available on the basement rocks of the Atlantic coasts of Africa and Brazil to allow a preliminary synthesis. But it seems certain that the rifting followed an ancient intercratonic structural trend (mobile belt) with a complex history of metamorphism and magmatism (Fyfe and Leonardos, 1973). The rifting process was not random.

Brazilian Metamorphic Patterns An outline of the metamorphic belts and charnockite distribution in Eastern Brazil is presented in Fig. 1. Two major ancient nucleii are recognized: the São Francisco and the Paraná cratons. The first is largely covered by the $600 \mathrm{~m}$.y. old sediments of the Bambuí Series. In a few places where the cover is lacking gneisses older than 2,700 m.y. have been dated (Hasui and Almeida, 1970; Herz, 1970). The craton is surrounded by orogenic belts of Trans-Amazonic age (2,000 \pm 300 m.y.) on which later fold belts have been superposed. The 1,100 to 1,400 m.y. old Espinhaço fold belt (Cordani et al., 1968) was developed in its western border and the Brasília belt with ages ranging from 570 to 900 m.y. in the western border (Almeida, 1971). The existence of a Paraná craton below the thick Mesozoic basaltic lava flows and underlying

*Department of Geology University of Western Ontario, London, Canada

**Departamento de Geociências Universidade de Brasília, Brasil 


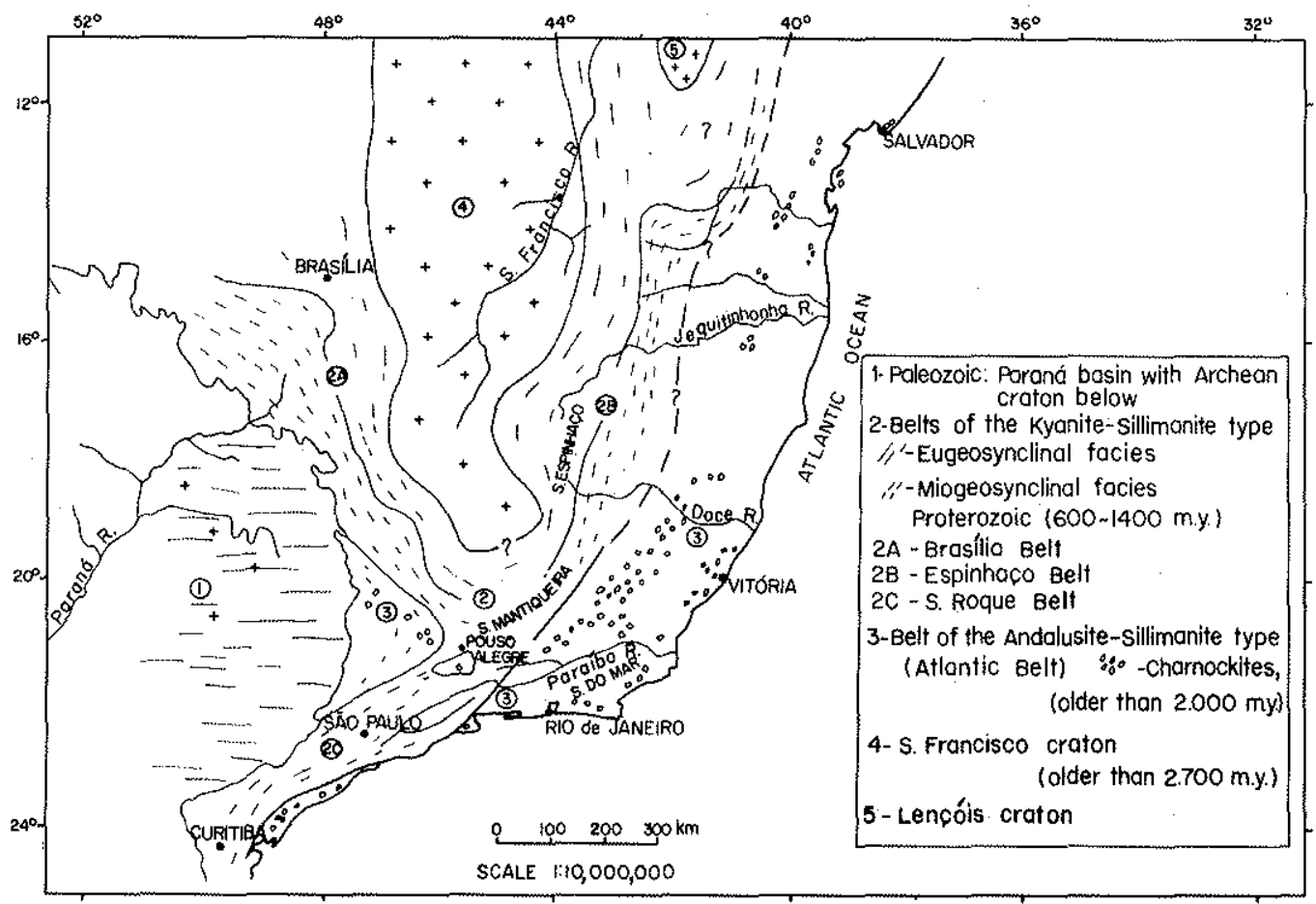

Figure 1 - Outline of the metamorphic belts in Eastern Brazil

Paleozoic sediments of the Paraná basin is still a matter of conjecture. Its presence is inferred from the overall pattern of the Brazilian Platform, particularly the fact that the Paraná basin is bordered by a polygonal arrangement of orogenic belts. African analogues, e.g. the Rhodesian craton, are well known, where a former basalt cover is largely stripped. In fact, such ancient cratons can only exist by being periodically covered; otherwise they. would simply dissolve away by erosion.

The older (Atlantic) belt is characterized by a low pressure/temperature metamorphic facies series (Abukuma type) while the younger ones (Espinhaço, Brasilia and São Roque belts) by Barrovian facies series.

Sillimanite-cordierite gneisses, granulites, charnockites, migmatites and granites of the Atlantic belt match with rocks of the same nature, metamorphism and age of the pre- Mayombien belt in Angola. An interesting fit is that of the charnockite belts. One belt runs for over a thousand kilometers, from the state of Parana through the states of Rio de Janeiro and Espirito Santo, in Brazil and continues in Angola (Delhal and Fiermans, 1964) for an additional 1,200 km, from near Luanda to the region of Luiza. The other charnockite belt, partly parallel to the former and over $2,000 \mathrm{~km}$ long, runs from the state of Goias to the north of Salvador and has its extension in Africa in the Congo and Gabon. As in Brazil, African charnockites are closely related to migmatites and thought to be the residue of anatexis. Present age data is still discrepant. The age of charnockitization in Congo and Angola is around 2,800 m.y. (Delhal and Ledent, 1971) while in Brazil preliminary results have yielded ages around 2,000 m.y. (Delhal et al., 1969). As repeated phases of partial melting should have taken place within the Atlantic belt and, consequently different period of charnockitization, and as most granulite terrain is retrograded to amphibolite facies, the first ages on Brazilian charnockites are not surprising, for the same 
2,000 m.y. event (Mendes and Vialette, 1972; Carvalho, 1972) is widespread in the migmatite complex of Angola.

Another charnockite belt in South America (see Berrangé, in press) is that of the Kanuku complex of the Guiana shield which has its equivalent in the Man massif of the Ivory Coast. The metamorphism in both complexes is again of the Abukuma type. The neighbouring Barrovian-type terrain represented by the schists and gneisses of the Ceará Series in Brazil and the Dahomeyan belt in Africa also provides a good fit as both metamorphic and age boundaries are coincident. The tectonic framework of both continents are schematized in Fig. 2. As similar relationship has been found already along the coasts of Madagascar, India, Ceylon, and Australia (Katz, 1972).

It should be stressed that experimental studies of the melting behaviour of crustal materials (Brown and Fyfe, 1970) have shown that rocks of the granulite facies and charnockites can be simply derived as the residue from partial melting of crustal metamorphic rocks. The partial melts belong to the granite family. The granulite facies metamorphic rocks exposed at the surface must represent the base of the granitic crust. It seems reasonable, that the large heat fluxes needed for migmatization may be associated with the rise of basaltic magma from the upper mantle. Thus one may expect a series of steps such as:

1) creation of a thermal anomaly in the upper mantle (plume) leading to surface basalt eruption and general heating of the crustal region;

2) fusion of the base of the crust and commencement of acid plutonism and volcanism;

3) once the base of the crust becomes "sticky" on a large scale, basalt cannot be extruded but instead it flows beneath the low viscosity crust. This basalt may differentiate to produce peridotite-anorthosite complexes because of the very long cooling time in a hot environment. Basaltic magmas may also be heavily contaminated by crustal materials and move towards andesitic compositions. Basalt injected at even greater depth could crystallize to eclogitic complexes. We would thus expect to find basaltic differentiates and anorthosite associated with the migmatite-charnockite regions. Studies on the Rio de Janeiro migmatites (Leonardos, 1973) show that the thermal gradient was high, perhaps $60{ }^{\circ} \mathrm{C} / \mathrm{km}$ or greater, the rocks being formed at pressures not greater than $4 \mathrm{~kb}$ and at temperatures around $700{ }^{\circ} \mathrm{C}$.

In general, in all Gondwanaland, Barrovian facies series are characteristic of the younger metamorphic belts (500 m.y. to 1,500 m.y.) while Abukuma facies series are characteristic of older ones (over 1,800 m.y.). High pressure/temperature facies series are unknown in rocks older than 900 m.y. This suggests a decrease in the average thermal gradient since Archean times of roughly $0.03{ }^{\circ} \mathrm{C} / \mathrm{m}$.y. The overall pattern of metamorphic belts surrounding the ancient cratons is suggestive of a very thin earlier crust, fractured during cooling into minimum energy polygonal patterns.

Models It thus appears that the separation of South America and Africa occurred along a line partly controlled by the presence of a former mobile belt where the base of the acidic crust was at a high level. The arguments presented below indicate that this may not be an accident.

We imagine that mantle thermal anomalies (plumes) can arrive under any crustal section by random processes. If a plume arrives beneath a continent with a thick granitic component, we might anticipate a series of events as follows:

1) dyking of the crust (some spreading) and surface eruption of basalts;

2) heating of the base of the crust until partial fusion commences. When extensive fusion has occurred basalt penetration ceases; 


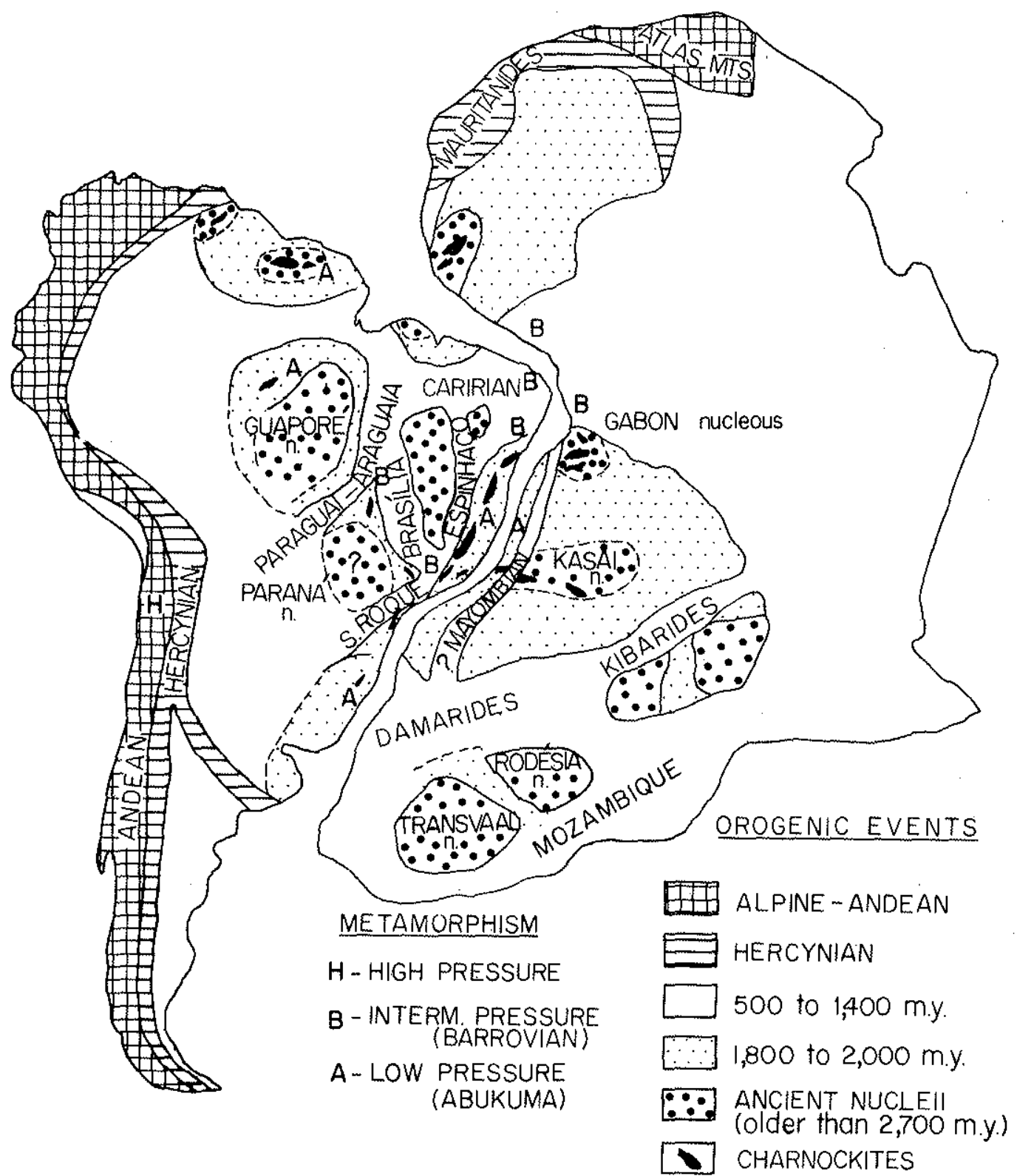

Figure 2 - Schematic tectonic framework of South America-Africa

3) granitic plutonism and acid volcanism;

4) synchronous with 3 , mantle basalt plumes spread beneath the crustal region developing at high levels anorthosite-peridotite complexes or at levels eclogite complexes.

Continuing action of the plume simply cycles basalt from depth and produces high level eclogite while mantle peridotite flows into the melting zone.

A similar plume may rise under a more basic and drier crustal section when granulites are at the surface. Flood basalts and dyking occurs. There is insufficient high level granitic phase to cut off basalt extrusion. A successful spreading ridge results and the con- 
tinent splits? We consider that such models may explain why old mobile belts become the sites for future continental fission and that the type of high grade metamorphic rocks on the Atlantic margins of South America and Africa are not pure accidents.

Finally, one cannot help being impressed by the continuity of flow of basaltic liquids at modern ocean ridge systems while at other times series after series of basalt dykes have attacked the old cratons but evidently basalt generation has been terminated before these are destroyed or fragmented. Again, there is perhaps a simple control. When a plume rises under a thick granitic crust, the first stage may involve dyke formation and basalt extrusion; the second stage crustal fusion. Basalt underplating and eclogite formation follows and may lead to a loading process depressing the upper surface of the mantle melting zone. This may drive the plumes to other sites. Thus under zones of thick granitic crust, plumes may be transient and will persist only under regions of thin acid crust, i.e., an ocean ridge type situation where most basaltic magma is injected near surface.

\section{REFERENCES}

ALMEIDA, F. F. M. - 1971 - Geochronological division of the Precambrian of South America. Rev. Bras. Geoc., 1: 13-21

BERRANGE, J. P. (in press). A synopsis of the geology of southern Guyana. Inst. Gcol. Sci., Overseas Division, 26. Also in Proc. IX Inter-Guyana Geol. Conf. Venezuela, 1972

BROWN, G. C. and FYFE, W.S. - 1970 - The production of granitic melts during ultrametamorphism. Contr. Mineral. and Petrol., 28: 310-318

CARVALHO, H. - 1972 - Chronologie des formation geologiques Precambriennes de la Region Centrale du Sud-Ouest de l'Angola et essai de correlation avec celles du Sud-Ouest Africa. XXIV Intern. Geol. Congr. (Montreal), 2: 187-194

CLIFFORD, T. N. - 1970 - The structural framework of Africa, in: African Magmatism and Tectonics. Ed. T. N. C:lifford and I. G. Gass, Oliver and Boyd, Edinburgh, pp. 1-26

CORDANI, U. G., MELCHER, G. C. and ALMEIDA, F. F. M. de - 1968 - Outline of the Precambrian geochronology of South America. Canad. J. Earth Sci. 5: 629-632

DELHAL, J. and FIERMANS, C. - 1964 - Extension d'un grand complexe charnockitique en Afrique Centrale. C. R. Ac. Sci. Paris, 259: 2665-2668

DELHAL, J. and LEDENT, D. - 1971 - Ages U/Pb et $\mathrm{Rb} / \mathrm{Sr}$ et rapport initiaux du strontium du complexe gabbronoritique et charnockitique du bouclier du Kasai (Republique Democratique du Congo et Angola). Ann. Soc. Géol. Belgique, 94: 211-221

DELHAL, J., LEDENT, D. and CORDANI, U. G. - $1969-$ Ages Pb/U, Sr/Rb et Ar/K des formations metamorphiques et granitique du sud-est du Brésil. Ann. Soc. Géol. Belgique, 92: 271-283

FYFE, W.S. and LEONARDOS, O. H. Jr. - 1973 - Ancient metamorphic-migmatite belts of the Brazilian-African Coasts. Nature 244: 501-502

HASUI, Y. and ALMEIDA, F. F. M. - 1970 - Geocronologia do centro-oeste brasileiro. Bol. Soc. Bras. Geol., 19 (1): 1-26

HERZ, N. - 1970 - Gneissic and igneous rocks of the Quadrilátero Ferrifero, Minas Gerais, Brazil. U.S. Geol. Survey, Prof. Paper 641-B, 58 pp.

KATZ, M. B. - 1972 - Facies Series of the high grade metamorphic rocks of the Ceylon Precambrian. XXIV Intern. Geol. Congr. (Montreal), 2: 45-51

LEONARDOS, O.H.Jr. - 1973 - The Origin and Alteration of Granitic Rocks in Brazil; A Study of Metamorphism, Anatexis, Weathering and Soil Fertility within Gramtic Terrain in Eastern Brazil. Univ. Manchester. Unpublished. Ph. D. Thesis

MENDES, F. and VIALETTE, Y. - 1972 - Le Precambrien de l'Angola. XXIV Intern. Geol. Congr. (Montreal), 1: 213-220

WARDLAW, N. C. and NICHOLS, G. D. - 1972 - Cretaceous evaporites of Brazil and West Africa and their bearing on the theory of Continent separation. XXIV Intern. Geol. Congr. (Montreal) 6: 43-55 